\title{
Ocena dynamiczna projektowanego kratownicowego mostu kolejowego w świetle Eurokodów
}

\author{
Radosław Oleszek ${ }^{1}$, Mirosław Wyrzykowski², Krzysztof Grej² ${ }^{2}$ Jerzy Bąk ${ }^{2}$ \\ ${ }^{1}$ Zakład Mostów, Wydziat Inżynierii Ladowej, Politechnika Warszawska, \\ e-mail:r.oleszek@il.pw.edu.pl \\ ${ }^{2}$ Pomost S.C, biuro projektowe, \\ e-mail:m.wyrzykowski@pomost.com.pl,k.grej@pomost.com.pl,j.bak@pomost.com.pl,
}

Streszczenie: Według nowelizacji Rozporządzenia „kolejowego” z czerwca 2014 obiekty inżynieryjne należy projektować na podstawie systemu norm PN-EN (Eurokodów), które rozszerzyły zakres analiz obliczeniowych na etapie projektowania konstrukcji o zagadnienia dynamiczne. Obejmują one teoretyczną analizę modalną (rozwiązanie zagadnienia własnego) wraz z oceną wrażliwości ustroju na wybrane formy drgań, sprawdzenie komfortu podróżnych oraz analizę czasową (całkowanie równań ruchu przy obciążeniu normowymi modelami pociągów szybkobieżnych HSLM). W niektórych przypadkach, przy planowanych prędkościach ruchu pociągów $v \leq 200 \mathrm{~km} / \mathrm{h}$, obliczenia dynamiczne można ograniczyć do analizy modalnej. W opracowaniu przedstawiono ocenę projektowanego kolejowego mostu kratownicowego o rozpiętości $L_{\mathrm{t}}=75,0 \mathrm{~m}$ pod względem dynamicznym, w świetle wymagań Eurokodów. Skomentowano wpływ zastosowanych rozwiązań konstrukcyjnych na charakterystyki modalne obiektu.

Słowa kluczowe: most kratownicowy, obiekt kolejowy, analiza dynamiczna, analiza modalna, Eurokody, MES.

\section{Wprowadzenie}

Według nowelizacji Rozporządzenia „kolejowego” [6] z czerwca 2014 obiekty inżynieryjne należy projektować na podstawie systemu norm PN-EN (Eurokodów) [4, 5]. W stosunku do dotychczasowych zasad, aktualne przepisy [6], standardy kolejowe [2, 3] i normy PN-EN $[4,5]$ rozszerzyły zakres analiz obliczeniowych na etapie projektowania konstrukcji o zagadnienia dynamiczne $[7 \div 12,14,16 \div 20]$. Współcześnie, pierwszym etapem analizy dynamicznej jest rozwiązanie problemu własnego, tj. wyznaczenie dominujących częstotliwości i form drgań własnych konstrukcji (teoretyczna analiza modalna $[8,9,15]$ ). W oparciu o te wielkości określa się zakres i dokładność kompleksowej analizy dynamicznej. W normie PN-EN 1991-2 [5] zamieszczono graficzny algorytm postępowania określający czy wymagana jest zaawansowana analiza czasowa (wyznaczenie odpowiedzi konstrukcji np. poprzez numeryczne całkowanie równań ruchu $[9 \div 11,15 \div 20])$ dla typowych, nieskomplikowanych obiektów mostowych obciążonych pociągami poruszającymi się z prędkościami do $200 \mathrm{~km} / \mathrm{h}$. W przypadku prędkości $v>200 \mathrm{~km} / \mathrm{h}$ taka analiza jest obligatoryjna. W niektórych jednak przypadkach obliczenia dynamiczne obiektu można ograniczyć do analizy modalnej.

$\mathrm{W}$ artykule przedstawiono ocenę konstrukcji projektowanego kolejowego mostu kratownicowego pod względem dynamicznym w świetle wymagań Eurokodów [4, 5]. Obiekt inżynieryjny o rozpiętości $L_{t}=75,0 \mathrm{~m}$ nad rzeką Drawą, został zaprojektowany w ramach 
modernizacji linii kolejowej E59 na odcinku Poznań Główny - Szczecin Dąbie. Na rozpatrywanym odcinku Krzyż - Dobiegniew (Lot D) prędkość projektowa wynosi $v=140 \mathrm{~km} / \mathrm{h}$, z możliwością przyszłego zwiększenia do $v=150 \mathrm{~km} / \mathrm{h}$. Most zaprojektowano na klasę $k+3$ $\left(\alpha_{k}=1,33\right)$ według $[5,6]$.

Ocenę dynamicznych własności projektowanej konstrukcji kratownicowej wykonano zgodnie z wymaganiami Załącznika A, poz. A2.4.4 normy PN-EN 1990 [4] oraz według poz. 6.4.4 PN-EN 1991-2 [5], stosowanie do wytycznych $[1 \div 3,6]$. Sprawdzenie ustroju obejmowało:

- określenie zakresu i dokładności wymaganej analizy dynamicznej według poz. 6.4.4 PN-1991-2 [5] (nomogram na Rys. 6.9), tj. sprawdzenie czy wymagana jest analiza czasowa (całkowanie równań ruchu) konstrukcji obciążonej normowymi modelami pociągów szybkobieżnych HSLM,

- wyznaczenie dominujących częstotliwości i form drgań własnych "kratownicy" o węzłach sztywnych,

- sprawdzenie wrażliwości na drgania giętne poziome z uwagi na możliwość wężykowania taboru i uderzeń bocznych zestawów kołowych o szyny według poz. A2.4.4.2(3) PN-EN 1990 [4] (określenie pierwszej częstotliwości bocznych drgań własnych przęsła $f_{\text {hmin }}$ ),

- sprawdzenie wrażliwości ustroju na skrętne formy drgań według poz. 6.4.4(1) PNEN 1991-2 [5],

- sprawdzenie konstrukcji w zakresie przyspieszeń w pudłach wagonów odpowiadających bardzo dobremu komfortowi podróżnych $\left(b_{v} \leq 1,0 \mathrm{~m} / \mathrm{s}^{2}\right)$ według poz. A2.4.4.3.2 PN-EN 1990 [4],

- sprawdzenie ugięć konstrukcji $\mathrm{u}_{\mathrm{z}}$ wywołanych modelem obciążenia LM-71, w nawiązaniu do ograniczeń uwzględniających standard utrzymania toru, przedstawionych w opracowaniu [15], tj. $\delta_{\text {stat }} \leq L /(15 v-400)$.

$\mathrm{Na}$ podstawie przeprowadzonej oceny ustroju pod względem dynamicznym, na etapie sporządzania projektu wprowadzono odpowiednie korekty sposobu konstruowania szczegółów.

\section{Charakterystyka obiektu}

Obiekt zaprojektowano w postaci jednoprzęsłowej kratownicy przestrzennej, w układzie wolnopodpartym o rozpiętości teoretycznej $\mathrm{L}_{t}=75,0 \mathrm{~m}$ (Rys. 1). Elementy ustroju przyjęto ze stali klasy S 355, beton koryta balastowego (płyty pomostu) C35/45, a jego zbrojenie ze stali BST500S (A-IIIN). Węzły kratownicy skonstruowano jako sztywne.

Kratownica składa się z sześciu ,przedziałów” (odcinki między węzłami, licząc przy pasie dolnym) o długości 12,50 m każdy. Pod względem geometrycznym „przedziały” kratownicy stanowią trójkąty równoramienne. Wysokość osiowa konstrukcji (odległość pomiędzy osią pasa dolnego i górnego) wynosi 10,0 m. Ustrój nośny obiektu stanowią dwa dźwigary kratowe płaskie w rozstawie osiowym 5,70 m. Pasy dolne kratownic połączone są za pomocą skrzynkowych poprzecznic węzłowych $b \times h=0,50 \mathrm{~m} \times 0,70 \mathrm{~m}$ i dwuteowych poprzecznic międzywęzłowych $b \times h=0,30 \mathrm{~m} \times 0,70 \mathrm{~m}$ oraz skratowań typu $\mathrm{K}$ (tężniki), a górą za pomocą stężeń poprzecznych i skratowań typu X. Połączenia elementów kratownicy zaprojektowano w postaci węzłów sztywnych (przenoszą siły osiowe, momenty zginające w dwóch kierunkach i momenty skracające). Układ tak połączonych prętów tworzy przestrzenny ustrój prętowo-ramowy. Wysokość geometryczna kratownicy wynosi 11,30 m, a szerokość $6,30 \mathrm{~m}$. 


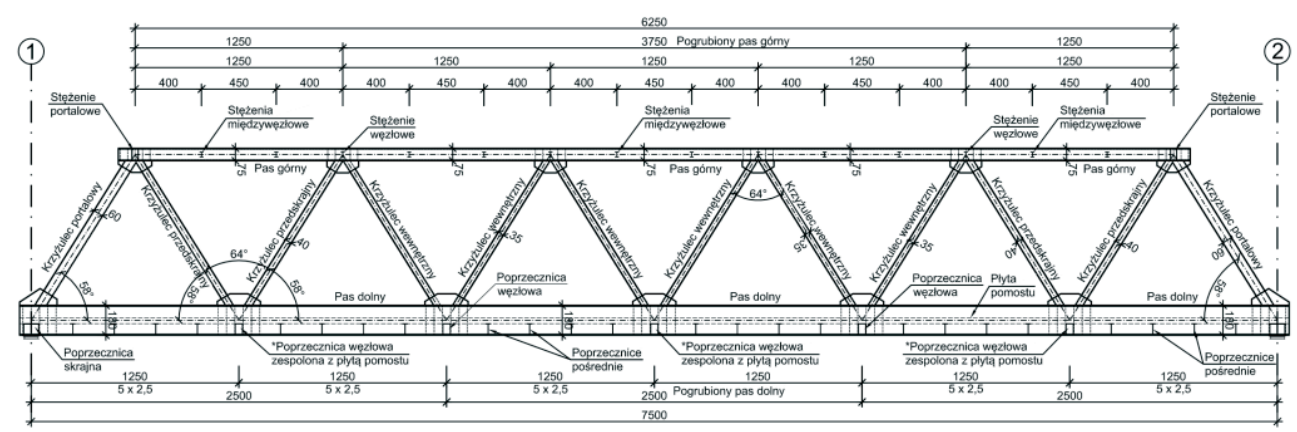

Rys. 1. Geometria projektowanej konstrukcji (widok z boku)

Pasy górne to przekroje skrzynkowe typu " $\pi$ " o wymiarach zewnętrznych $b \times h=$ $0,60 \mathrm{~m} \times 0,75 \mathrm{~m}$. Pasy dolne przyjęto $\mathrm{w}$ formie blachownic dwuteowych o jednakowej szerokości pasów i gabarytach zewnętrznych $b \times h=0,60 \mathrm{~m} \times 1,80 \mathrm{~m}$. Ze względu na koniczność oparcia konstrukcji kratowej na łożyskach o wymiarach około 0,80 $\mathrm{m} \times 0,80 \mathrm{~m}$ i występowanie blachy nadłożyskowej dolna półka blachownic w rejonie podpór (pas dolny kratownicy) została poszerzona do 1,0 m. Pasy dolne kratownic stężone są za pomocą poprzecznic węzłowych (przekroje skrzynkowe $b \times h=0,50 \mathrm{~m} \times 0,70 \mathrm{~m}$ ), międzywęzłowych (dwuteowniki $b \times h=0,30 \mathrm{~m} \times 0,70 \mathrm{~m}$ ) oraz skratowania typu $\mathrm{K}$ (dwuteownik). Krzyżulce zaprojektowano w formie zamkniętych przekrojów skrzynkowych. Krzyżulce portalowe przyjęto o obrysie zewnętrznym $b \times h=0,60 \mathrm{~m} \times 0,60 \mathrm{~m}$, krzyżulce przedskrajne $b \times h=$ $0,60 \mathrm{~m} \times 0,40 \mathrm{~m}$, a krzyżulce pośrednie (wewnętrzne) $b \times h=0,60 \mathrm{~m} \times 0,35 \mathrm{~m}$.

Przy podporach konstrukcji ukształtowano ramy portalowe pełniące rolę elementu zapewniającego stateczność globalną całego ustroju. Rygiel ramy portalowej przyjęto o przekroju skrzynkowym $b \times h=0,40 \mathrm{~m} \times 0,75 \mathrm{~m}$.

W obiekcie zastosowano układ łożyskowania zapewniający symetryczne przekazywanie reakcji poziomej na łożyska. Na podporze P-1 (Rys. 1), pod dźwigarami występują łożyska wielokierunkowo przesuwne. W środku odległości między dźwigarami, na poprzecznicy podporowej przyjęto łożysko z przesuwem w kierunku osi podłużnej obiektu $x$ oraz w kierunku pionowym $z$ (nie przenosi reakcji pionowej). W tym łożysku zablokowany jest przesuw w kierunku poprzecznym y obiektu. Na podporze P-2, pod dźwigarami (kratownicami) występują zewnętrzne łożyska wielokierunkowo przesuwne. W środku odległość pomiędzy kratownicami przyjęto punkt stały przenoszący reakcje poziomie w kierunku poprzecznym i podłużnym obiektu, pełniący rolę łożyska stałego (nie przenosi reakcji pionowej). Przyjęte rozwiązanie ma istotny wpływ na parametry modalne przęsła.

Specjalną uwagę zwrócono na wytężenie płyty pomostu (koryta balastowego). Element ten pracuje pod obciążeniem lokalnym (konstrukcją torowiska, modele pociągów), ale w pewnym stopniu współuczestniczy w globalnej pracy całego ustroju. Dodatkowe siły wewnętrzne występują w nim wskutek oddziaływań termicznych i skurczu betonu. Z uwagi na chęć zminimalizowania stopnia współpracy koryta balastowego z pasem dolnych kratownic (element ten przy zespoleniu z każdą z poprzecznic doznaje dodatkowych odkształceń wynikających z rozciągania pasów dolnych kratownicy) dokonano podziału (dylatacji) płyty na trzy niezależne sekcje długości około $25,0 \mathrm{~m}$ oraz zespolenia tylko na skrzynkowych poprzecznicach węzłowych. Umożliwia to ograniczenie wytężenia koryta balastowego wywołanego oddziaływaniami termicznymi i skurczowymi oraz zablokowaniem swobody odkształceń podłużnych w porównaniu $\mathrm{z}$ wariantem pełnego zespolenia na wszystkich poprzecznicach. Zastosowane rozwiązanie wpływa jednak na charakterystyki dynamiczne konstrukcji. 


\section{Model numeryczny konstrukcji}

Model numeryczny ustroju nośnego (Rys. 2) wykonano w postaci trójwymiarowej struktury belkowo-powłokowej (klasy $\mathrm{e}^{1}+\mathrm{e}^{2}, \mathrm{p}^{3}$ ) w środowisku MES SOFiSTiK. Modelem „kratownicy” o węzłach sztywnych jest rama przestrzenna (węzły sztywne w miejscu połączeń elementów). Pręty ustroju modelowano elementami belkowymi typu Timoszenko.

Koryto balastowe torowiska (płyta i burty) zamodelowano za pomocą trzech oddylatowanych sekcji paneli powierzchniowych, dyskretyzowanych skończonymi elementami powłokowymi typu Mindlina-Raissnera (uwzględniają stan zgięciowy i tarczowy oraz wpływ odkształceń postaciowych). Pełne zespolenie każdej sekcji płyty koryta występuje tylko na jednej poprzecznicy węzłowej. Na pozostałych poprzecznicach koryto opiera się swobodnie, z możliwością przesuwu po osi $x$ i $y$. Tylko przy dylatacjach sekcji zablokowane zostały przesuwy w kierunku $y$ (poprzecznym). Zespolenie i swobodne podparcie płyty koryta zamodelowano za pomocą więzów (połączeń) kinematycznych.

Stężenia górne typu X oraz stężenia dolne typu K, zamodelowano za pomocą belkowych elementów skończonych z obustronnymi przegubami. Poprzecznice i stężenia górne poprzeczne (prostopadłe do osi podłużnej obiektu) zamodelowano za pomocą elementów belkowych połączonych na sztywno z pasami. Krzyżulce połączone są z pasami kratownicy w sposób sztywny.

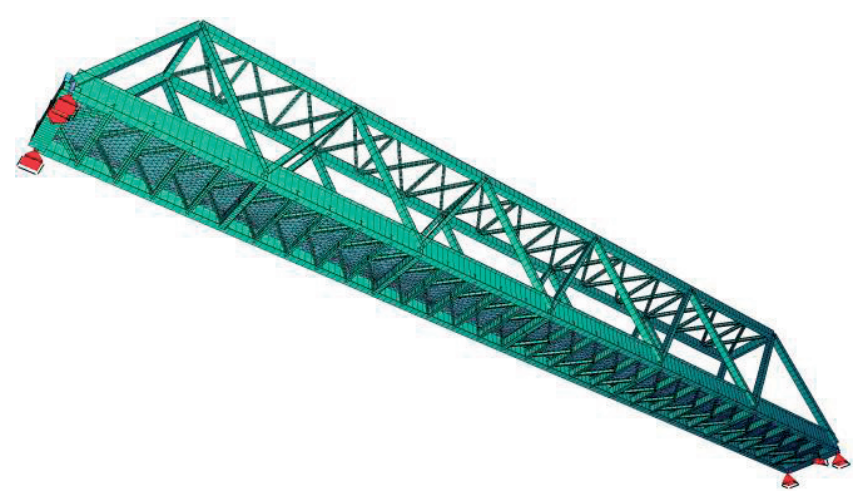

Rys. 2. Wizualizacje modelu numerycznego konstrukcji (klasy $\mathrm{e}^{1}+\mathrm{e}^{2}, \mathrm{p}^{3}$ )

Układ łożyskowania obiektu odwzorowano odbierając odpowiednie stopnie swobody (translacyjne lub rotacyjne) węzłom podporowym, które zlokalizowano w poziomie spodu dolnego pasa kratownic i poprzecznic podporowych (rzeczywiste usytuowanie łożysk).

\section{Metoda obliczeń dynamicznych}

Teoretyczną analizę modalną (określenie częstotliwości i odpowiadających im form drgań własnych) konstrukcji kratownicowej wykonano w module ASE środowiska MES SOFiSTiK. W zagadnieniach drgań własnych nie występują wymuszenia zewnętrzne $[8,9,15]$. Wektor obciążeń przyjmuje wartość zerową i pomija się thumienie. Zgodnie $\mathrm{z}$ zasadą d'Alamberta, w równaniu równowagi, siły bezwładności uwzględnia się jako część sił masowych. Różniczkowe równanie ruchu (równanie równowagi dynamicznej) opisuje zależność (1). W ogólnym przypadku, jego rozwiązanie polega na znalezieniu pierwiastków równania charakterystycznego (zagadnienie własne) opisanego wzorem (2). 


$$
\begin{aligned}
& \mathbf{M} \ddot{\mathbf{u}}(t)+\mathbf{K u}(t)=0 \\
& \operatorname{det}\left|\mathbf{K}-\omega^{2} \mathbf{M}\right|=0
\end{aligned}
$$

We wzorach (1) i (2) przyjęto oznaczenia: $\mathbf{M}$ - macierz mas (bezwładności), $\mathbf{K}$ - macierz sztywności, $\omega$ - częstość kołowa (poszukiwana częstotliwość $f=\omega / 2 \pi$ ), $\ddot{\mathbf{u}}(t)$ - wektor przyspieszeń, $\mathbf{u}(t)$ - wektor przemieszczeń.

Z uwagi na znaczną liczbę dynamicznych stopni swobody (DSS) układu, w obliczeniach wykorzystano wydajny numerycznie iteracyjny algorytm wektorów Lanczosa, przystosowany do poszukiwania kilku spośród wielu wartości rozwiązania $[8 \div 11,13]$. W tym celu wykorzystuje się transformację zagadnienia do postaci uogólnionej:

$$
\begin{aligned}
& \mathbf{K} \Phi_{\mathbf{u}}-\mathbf{M} \omega^{2} \boldsymbol{\Phi}_{\mathbf{u}}=0 \Rightarrow \quad \mathbf{K} \Phi_{\mathbf{u}}=\mathbf{M} \omega^{2} \boldsymbol{\Phi}_{\mathbf{u}} \\
& \lambda=\omega^{2} \Rightarrow \quad \mathbf{K} \Phi_{\mathbf{u}}=\lambda \mathbf{M} \Phi_{\mathbf{u}}
\end{aligned}
$$

gdzie: $\boldsymbol{\Phi}_{\mathbf{u}}$ - wektor postaci drgań własnych (wektor amplitud uogólnionych drgań swobodnych), $\lambda$ - poszukiwana wartość własna, $\mathbf{M}$ - macierz mas, $\mathbf{K}$ - macierz sztywności.

Metoda Lanczosa polega na transformacji zagadnienia własnego, sformułowanego w ujęciu uogólnionym według równania (4), do postaci standardowej z macierzą trójdiagonalną T, opisaną zależnością:

$$
\mathbf{T}=\mathbf{Q}_{j}^{\mathrm{T}} \mathbf{M K}^{-1} \mathbf{M} \mathbf{Q}_{j}
$$

w której: $\mathbf{Q}_{\mathbf{j}}=\left[\mathbf{q}_{1}, \mathbf{q}_{2}, \ldots, \mathbf{q}_{\mathrm{j}}\right]-$ macierz prostokątna $n \times j$ zawierająca wektory Lanczosa, przy czym $n$ oznacza liczbę iteracji (kroków) metody, $\mathbf{q}_{\mathrm{j}}$ to j-ty wektor Lanczosa.

Wartości własne macierzy $\mathbf{T}$ są odwrotnościami wartości własnych zagadnienia własnego według równania (4). Metoda ma charakter iteracyjny (kolejnych przybliżeń), co oznacza, że w j-tym przybliżeniu uzyskuje się wymaganą liczbę par wartość własna i odpowiadający jej wektor własny, tj.: $\left(\omega_{1}^{2}, \mathbf{q}_{1}\right),\left(\omega_{2}^{2}, \mathbf{q}_{2}\right), \ldots,\left(\omega_{\mathrm{n}}{ }^{2}, \mathbf{q}_{\mathrm{n}}\right)$. Wektory własne ostatecznie określane są z wykorzystaniem macierzy transformacji $\mathbf{s}_{\mathrm{k}}$ według zależności:

$$
\boldsymbol{\Phi}_{\mathrm{u}}=\mathbf{Q}_{j} \mathbf{s}_{k}
$$

Algorytm Lanczosa stosuje się powszechnie do rozwiązywania zagadnień drgań własnych konstrukcji o znacznej liczbie dynamicznych stopni swobody w większości dostępnych systemów MES. Jest efektywny obliczeniowo, a wprowadzone w ostatnich latach poprawki i uzupełnienia powodują, że procedura jest stabilna numerycznie.

W obliczeniach drgań własnych uwzględniono ciężary elementów niekonstrukcyjnych (wyposażenie - podsypka tłuczniowa, podkłady, szyny), dokonując konwersji obciążeń powierzchniowych na równoważne masy węzłowe.

\section{Wyniki symulacji numerycznych}

\subsection{Analiza modalna}

Na podstawie wykonanego przestrzennego modelu belkowo-powłokowego konstrukcji kratownicowej (klasy e $\mathrm{e}^{1}+\mathrm{e}^{2}, \mathrm{p}^{3}$ ) wyznaczono podstawowe częstotliwości i odpowiadające im formy drgań własnych. Wizualizacje postaci własnych i wartości częstotliwości zestawiono w tab.1. 
Zakres dopuszczalnych częstotliwości, przy których nie jest wymagana analiza czasowa określono zgodnie z wytycznymi normowymi według poz. 6.4.4 PN-EN 1991-2 [5]:

- górna granica częstotliwości $n_{0 g}$, będąca wynikiem nadwyżek dynamicznych uwzględniających nierówności toru:

$n_{0 g}=94,76 \times L^{-0,748}=94,76 \times 75^{-0,748}=3,75 \mathrm{~Hz}$,

- dolna granica częstotliwości $n_{0 \mathrm{~d}}$, będąca wynikiem nadwyżek dynamicznych uwzględniających dynamiczne oddziaływanie taboru:

$n_{0 d}=23,58 \times L^{-0,592}=23,58 \times 75^{-0,592}=1,83 \mathrm{~Hz}$.

Tabela 1. Zestawienie podstawowych częstotliwości i form drgań własnych konstrukcji z modelu MES

$$
\text { 1. } f=1,24 \mathrm{~Hz} \quad 2 . f=2,23 \mathrm{~Hz}
$$

Pierwsza forma drgań giętnych poziomych (bocznych), fala pojedyncza, forma symetryczna

Pierwsza forma drgań giętnych pionowych, fala pojedyncza, forma symetryczna

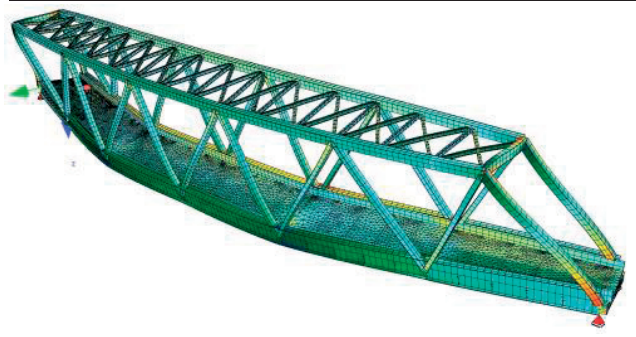

3. $f=2,83 \mathrm{~Hz}$

Drgania giętne poprzeczne kratownicy (ramy) i skrętne pomostu, forma symetryczna

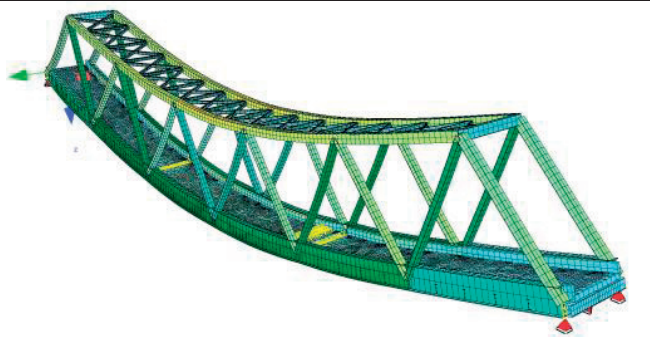

4. $f=3,47 \mathrm{~Hz}$

Pierwsza forma drgań podłużnych (osiowych) kratownicy z giętną formą drgań pasa dolnego i krzyżulców

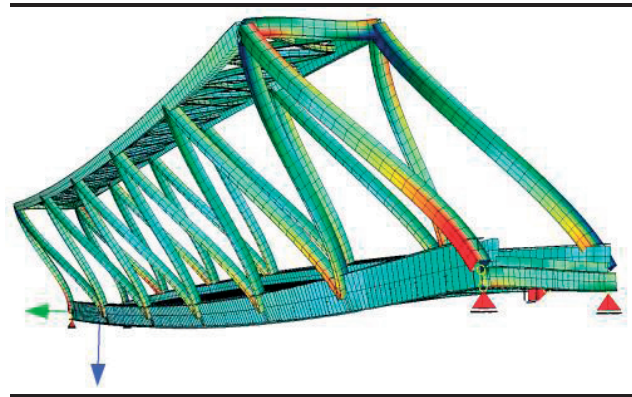

5. $f=3,78 \mathrm{~Hz}$

Druga forma drgań giętnych poziomych (bocznych) kratownicy

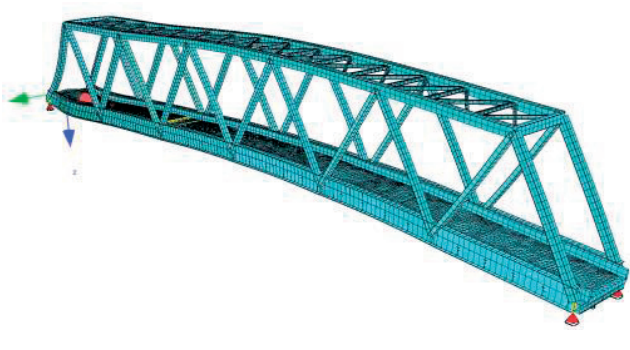

6. $f=4,93 \mathrm{~Hz}$

Trzecia forma drgań giętnych poziomych z stowarzyszoną antysymetryczną formą drgań poprzecznych, fala podwójna

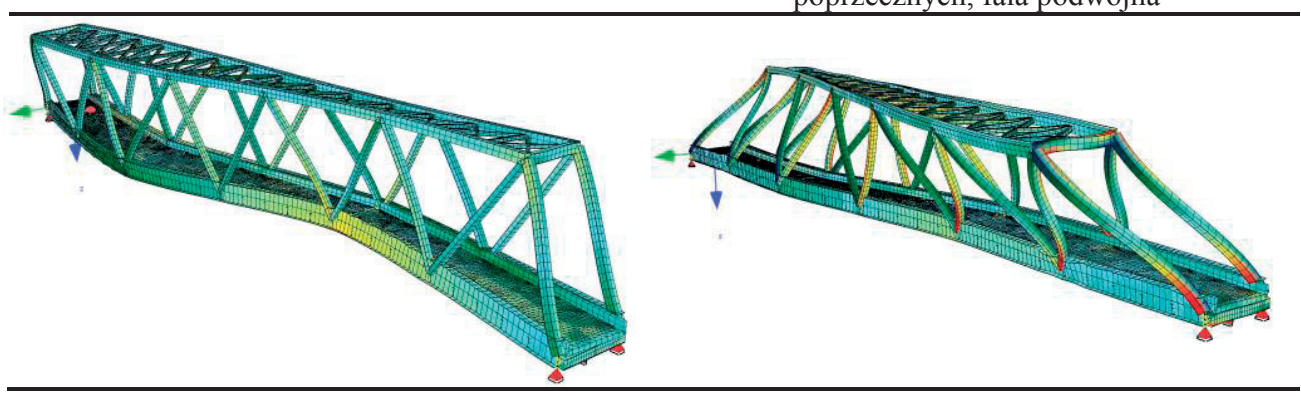


Częstotliwość pierwszej giętnej postaci drgań własnych konstrukcji z modelu MES wynosi $n_{0}=2,23 \mathrm{~Hz}$ i mieści się w zakresie $1,83 \div 3,75 \mathrm{~Hz}$ (nomogram na Rys. 3 ). Na Rys. 4 przedstawiono diagram zgodny z poz. 6.4.4 PN-EN 1991-2 [5], określający czy w przypadku rozpatrywanej konstrukcji kratownicowej konieczna jest zaawansowana analiza dynamiczna (całkowanie równań ruchu ustroju obciążonego pociągami szybkobieżnymi HSLM) oraz obliczenia zmęczeniowe. Zidentyfikowane teoretyczne częstotliwości i formy drgań oraz ich proporcje, przy zakładanej prędkości ruchu pociągów $v=150 \mathrm{~km} / \mathrm{h}$, umożliwiają ograniczenie obliczeń dynamicznych kratownicy do analizy modalnej (rozwiązania zagadnienia własnego). Poza tym częstotliwość drgań bocznych giętnych $f_{\text {hmin }}=1,24 \mathrm{~Hz}>f_{h 0}=$ 1,20 Hz, co oznacza, że w świetle poz. A2.4.4.2(3) PN-EN 1990 [4] konstrukcja jest niewrażliwa na drgania boczne, wywołane np. wężykowaniem taboru. Proporcja częstotliwości form skrętnych i giętnych $n_{T}=2,83 \mathrm{~Hz}>1,2 \cdot n_{0}=2,68 \mathrm{~Hz}$, wskazuje, że ustrój jest niewrażliwy, z niewielkim zapasem rzędu 5,6\%, na skrętne postacie drgań pomostu.

Przyjęte rozwiązania konstrukcyjne determinują charakterystyki częstotliwościowe modelu numerycznego konstrukcji i wpływają na jej wrażliwość na wybrane formy drgań. Zastosowany układ łożyskowania jest korzystny z punktu widzenia równomiernego (symetrycznego) przekazywania reakcji poziomej od sił hamowania, przyspieszania i parcia wiatru na przyczółki. Zastosowanie łożyska stałego usytuowanego mimośrodowo w stosunku do osi symetrii podłużnej konstrukcji powodowałoby powstawania dodatkowych reakcji poziomych w kierunku poprzecznym, z uwagi na mimośród wypadkowej względem punktu stałego. Niestety, w kontekście dynamicznego zachowania się ustroju, zwiększa się jego wrażliwość na poziome formy drgań (zmniejsza się częstotliwość giętnych drgań poziomych dążąc do wartości granicznej, tj. $f_{h 0} \rightarrow f_{h \min }=1,20 \mathrm{~Hz}$ ), które mogą zostać wzbudzone na skutek wężykowania taboru (uderzeń bocznych zestawów kołowych o szyny). Ma to szczególne znaczenie w konstrukcjach wolnopodpartych o dużych rozpiętościach, jak rozpatrywany most.

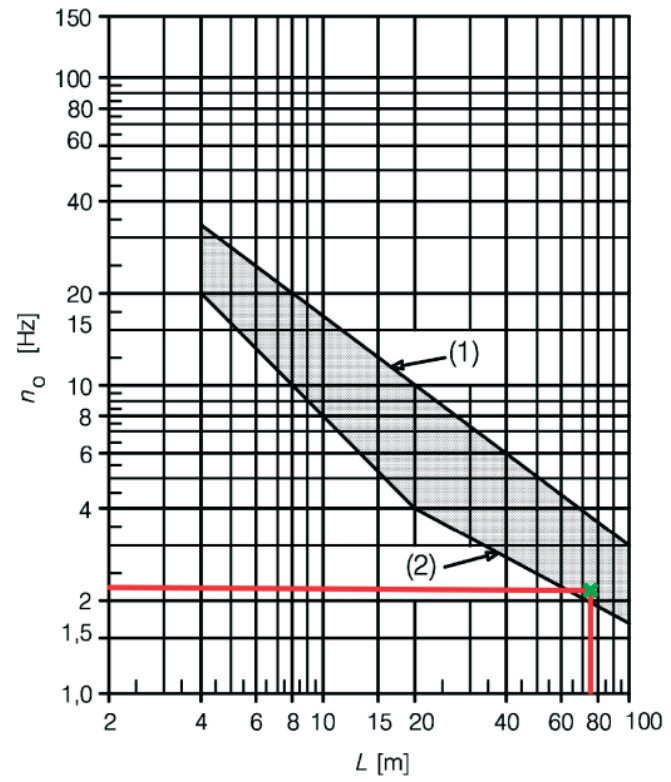

Górna granica częstotliwości (nierówności toru)

$n_{0}=94,76 \cdot L^{-0,748}$

Dolna granica częstotliwości (dynamiczne oddziaływanie taboru)

$$
\begin{array}{lc}
n_{0}=80 / L & 4 \mathrm{~m} \leq L_{\Phi} \leq 20 \mathrm{~m} \\
n_{0}=23,58 \cdot L^{-0,592} & 20 \mathrm{~m} \leq L_{\Phi} \leq 100 \mathrm{~m}
\end{array}
$$

$n_{0}$ - pierwsza częstotliwość drgań własnych uwzględniająca masę od oddziaływań stałych

$L$ - rozpiętość przęseł wolnopodpartych lub rozpiętość miarodajna $L_{\Phi}$ dla pozostałych schematów statycznych

(1) - obwiednia górna częstotliwości

(2) - obwiednia dolna częstotliwości

Rys. 3. Określenie zakresu częstotliwości form giętnych konstrukcji na podstawie Rys. 6.10 PN-EN 1991$2[5]$ 
EN 1991-2:2003

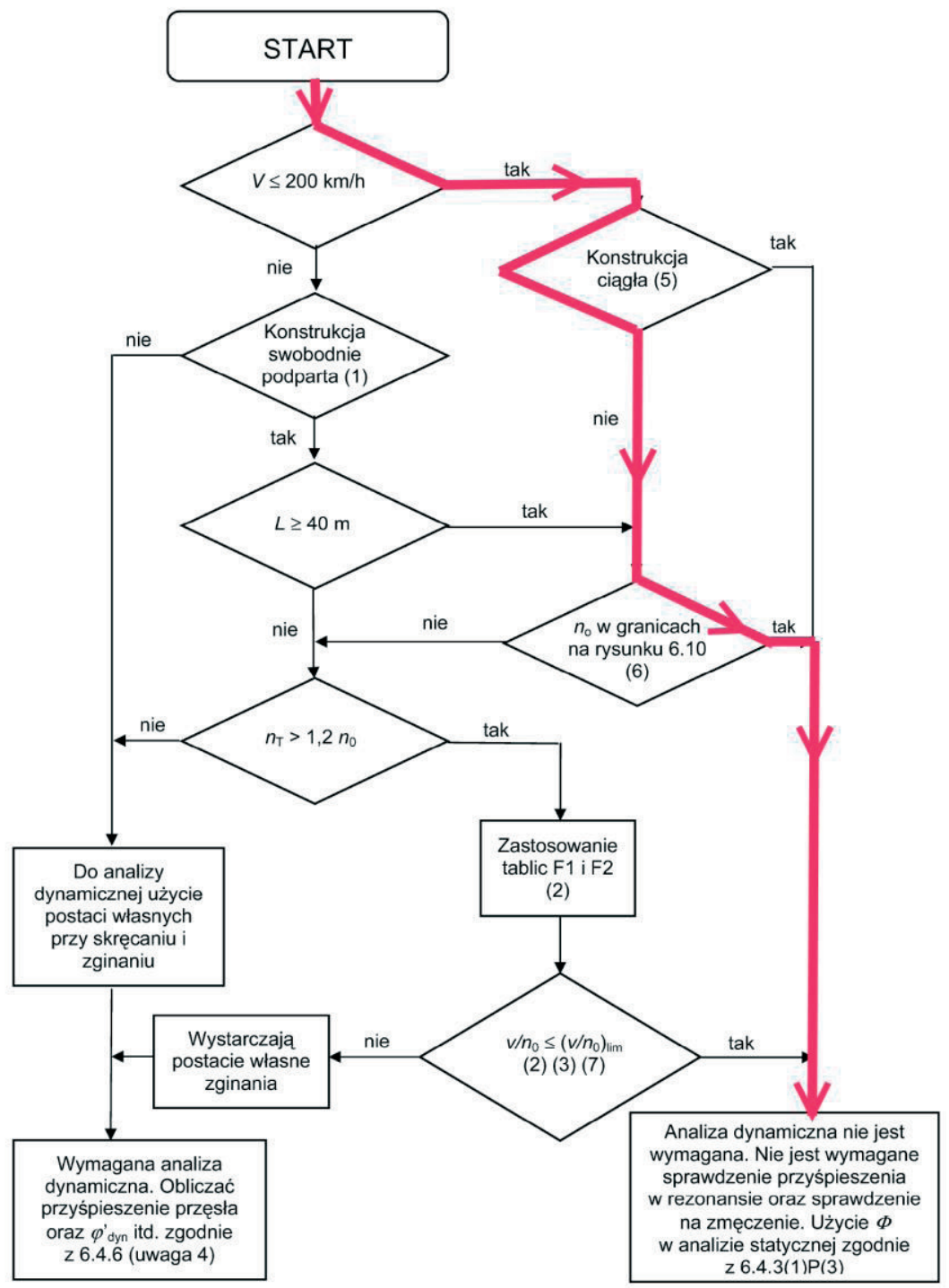

Rysunek 6.9 - Algorytm wyznaczania czy wymagana jest analiza dynamiczna

Rys. 4. Określenie czy wymagana jest zaawansowana analiza dynamiczna konstrukcji (analiza czasowa całkowanie równań ruchu) oraz obliczenia zmęczeniowe według poz. 6.4.4 PN-EN 1991-2 [5]

Zdylatowanie i podział płyty pomostu (koryta balastowego) na trzy odcinki o długościach $\sim 25,0 \mathrm{~m}$ jest korzystne ze względów statyczno-wytrzymałościowych. Umożliwia swobodę odkształceń i znaczne ograniczenie wytężenia płyty, związanego z rozciąganiem pasa dolnego kratownic przy wariancie z pełnym zespoleniem oraz następstw zjawisk termicznych i skurczowych. Płyta pomostu stanowi tarczę żelbetową nadającą sztywność konstrukcji w płaszczyźnie poziomej, w kierunku poprzecznym. Podział płyty na trzy 
odcinki i zespolenie z jedną poprzecznicą powoduje redukcję globalnej sztywności kratownicy w kierunku poziomym. Podobnie jak w przypadku łożysk, efektem jest obniżenie częstotliwości drgań bocznych (poziomych). W celu zwiększenia sztywności poziomej należało zablokować przesuwy koryta balastowego w kierunku poprzecznym przy dylatacjach. Zabieg ten spowodował, że $f_{\mathrm{h} 0}>1,20 \mathrm{~Hz}$, co jest zgodne z PN-EN 1990 [4]. W analizowanej konstrukcji podjęto próby zwiększenia sztywności poprzecznej, tak aby $f_{h 0} \gg f_{h \min }=1,20 \mathrm{~Hz}$, poprzez zastosowanie silniejszych stężeń typu $\mathrm{K}$ usytuowanych w poziomie pasa dolnego i stężeń typu X przy górnych pasach kratownic, ale skuteczność tego zabiegu była niewielka.

Proporcje i wartości częstotliwości $n_{T}=2,83 \mathrm{~Hz}>1,2 \cdot n_{0}=2,68 \mathrm{~Hz}$ świadczą, że zgodnie z Eurokodem $\mathrm{w}$ analizowanej konstrukcji nie powinny zostać wymuszone drgania skrętne. Skrętne formy drgań są szczególnie niekorzystne w mostach dwutorowych, gdzie zostają wzbudzane przez obciążenia pionowe od taboru poruszającego się po jednym $\mathrm{z}$ torów. W przypadku ustrojów jednotorowych, jak rozpatrywany most, drgania skrętne mogą być wywołane przez pewne specyficzne oddziaływania taboru kolejowego, np.: uderzenia boczne kół o szyny (wężykowanie), z uwagi na mimośrodowe przyłożenie sił poziomych w stosunku do środka ciężkości pomostu, oddziaływanie boczne wiatru na tabor kolejowy (niesymetryczne obciążenie kół pociągów). W obiektach skośnych lub zakrzywionych w planie szczególnie niebezpieczne może być nakładanie się giętnych i skrętnych postaci drgań.

W przypadku gdyby nie udało się spełnić warunków na częstotliwość $n_{0}$ zawartej W granicach z Rys. 3 (6.10 w normie [5]) oraz $n_{T}>1,2 \cdot n_{0}$ projektowana konstrukcja nie była by zdyskwalifikowana pod względem dynamicznym. Konieczne byłoby jednak przeprowadzenie zaawansowanej analizy dynamicznej (czasowej - całkowanie równań ruchu) konstrukcji, obciążonej modelami pociągów szybkobieżnych HSLM, z uwzględnieniem postaci drgań giętnych i skrętnych.

\subsection{Sprawdzenie komfortu podróżnych}

Zgodnie z wymaganiami A2.4.4.3 PN-EN 1990 [4] komfort pasażera zależy od przyspieszenia pionowego $b_{v}$ wewnątrz pojazdu (pudła wagonu). W tablicy A2.9 podano zalecane poziomy komfortu i odpowiadające im graniczne wartości przyspieszeń w pudłach wagonów $b_{v}$, przy czym $b_{v}=1,0 \mathrm{~m} / \mathrm{s}^{2}-$ bardzo dobry poziom komfortu, $b_{v}=1,3 \mathrm{~m} / \mathrm{s}^{2}-$ dobry, $b_{v}=2,0 \mathrm{~m} / \mathrm{s}^{2}-$ dostateczny. Przyspieszenie $b_{v}$ wewnątrz pojazdu może być oszacowane dwoma metodami:

- na podstawie dynamicznej analizy czasowej (całkowanie równań ruchu) współdziałania pociągu o resorowanym zawieszeniu z konstrukcją mostu i z uwzględnieniem parametrów lepko-sprężystych torowiska, przy czym ten typ analizy wymaga zaawansowanych procedur numerycznych i znajomości rodzaju taboru przewidzianego na danym odcinku linii kolejowej oraz charakterystyk sprężysto-tłumiących zawieszenia pociągów i torowiska,

- z wykorzystaniem ograniczeń ugięć pionowych przęsła $\mathrm{u}_{\mathrm{zmax}}$, wywołanych statycznym modelem obciążenia klejowego LM-71 według PN-EN 1991-2 [5] (poz. 6.3.2) mnożonym przez współczynnik dynamiczny $\Phi$ oraz współczynnik sklasyfikowanego obciążenia pionowego $\alpha_{k}=1,0$, przy czym ugięcia dopuszczalne $\delta_{d o p}$, będące funkcją prędkości ruchu pociągów $v$, schematu statycznego i rozpiętości przęseł mostu, określa się na podstawie nomogramu na Rys. A2.3 PN-EN 1990 [4]. 
Wartości $L / \delta_{\text {dop }}$ przedstawione na Rys. A2.3 [4] dotyczą szeregu belek swobodnie podpartych, z co najmniej 3 przęsłami. W przypadku pojedynczego przęsła wartości $L / \delta_{\text {dop }}$ odczytane z nomogramu na Rys A2.3 należy mnożyć przez 0,7 , ale tylko przy $L / \delta_{\text {dop }}>600$. Wartości $L / \delta_{\text {dop }}$ na Rys. A2.3 dotyczą przęseł o długościach $L<120 \mathrm{~m}$.

Na Rys. 5. określono wartości ugięć dopuszczalnych, zapewniających bardzo dobry poziom komfortu podróżnych $\left(b_{v}<1,0 \mathrm{~m} / \mathrm{s}^{2}\right)$, przy planowanej prędkości ruchu pociągów $v=150 \mathrm{~km} / \mathrm{h}$. Na Rys. 6 przedstawiono obwiednię wartości ugięć $u_{z}$, wywołanych modelem obciążenia statycznego LM-71× $\Phi \times \alpha_{\mathrm{k}}$.

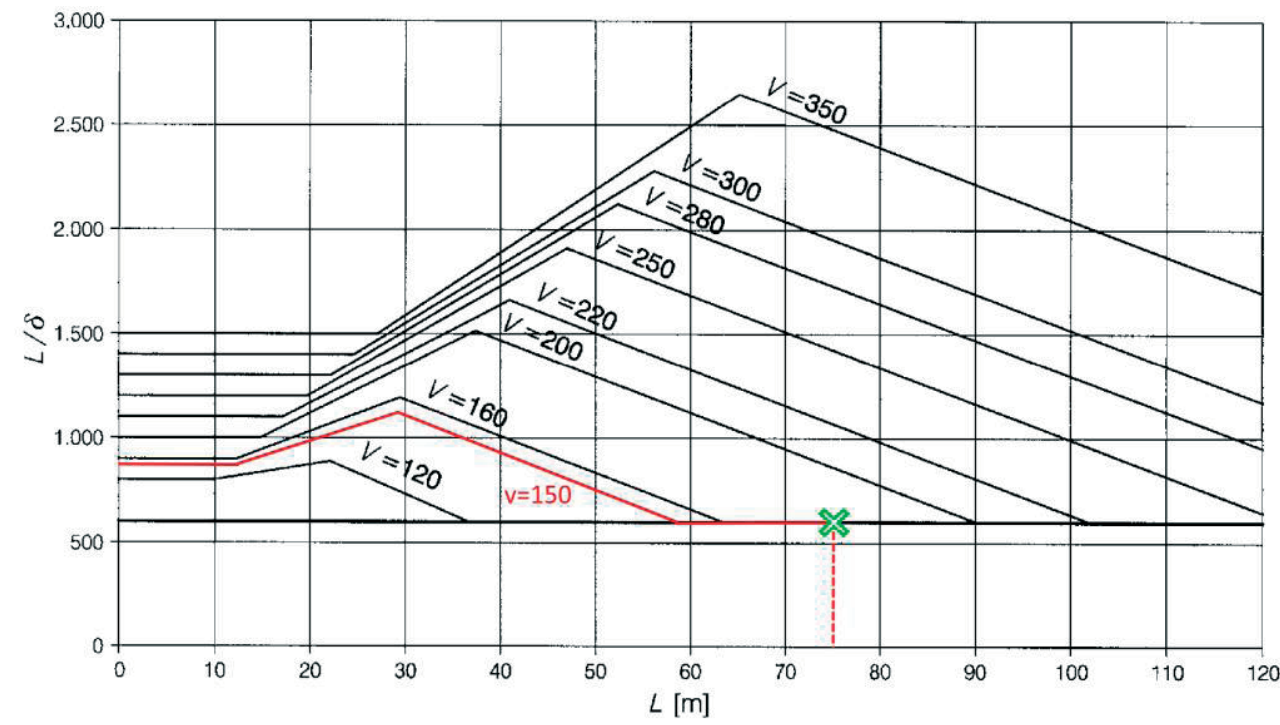

Rys. 5. Określenie ugięć dopuszczalnych $\delta_{\text {dop }}$ zapewniających bardzo dobry komfort podróżnych (przyspieszenia w pudłach wagonów $b_{v}=1,0 \mathrm{~m} / \mathrm{s}^{2}$ ) na podstawie Rys. A2.3. PN-EN 1990 [4]

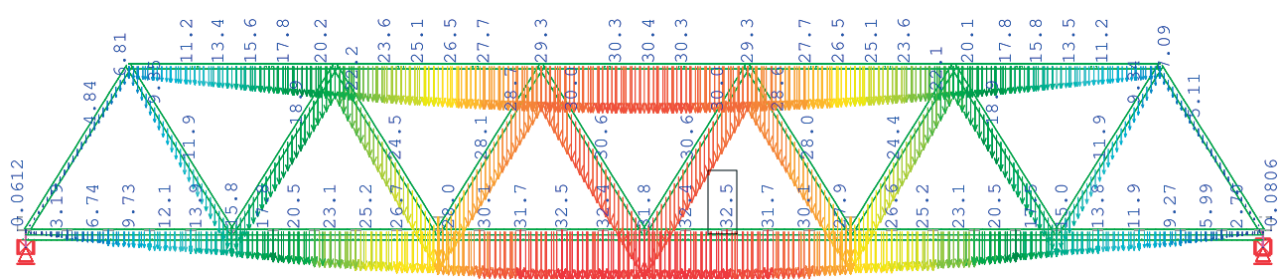

Rys. 6. Ugięcia pionowe $u_{z}[\mathrm{~mm}]$ wywołane modelem obciążenia statycznego LM-71 $\times \Phi \times \alpha_{\mathrm{k}}$ (obwiednia)

Zgodnie z poz. A2.4.4.3 PN-EN 1990 [4] przy prędkości $v=150 \mathrm{~km} / \mathrm{h}$ i rozpiętości konstrukcji $L_{t}=75,0 \mathrm{~m}$, stosunek $L / \delta_{\text {dop }}=600$, natomiast ugięcia dopuszczane przy bardzo dobrym komforcie podróżnych $\delta_{d o p}=(7500 \mathrm{~cm} / 600)=12,5 \mathrm{~cm}$. Ustrój spełnia warunek ugięć, tj. $u_{z \max }\left(\mathrm{LM}-71 \times \Phi \times \alpha_{\mathrm{k}}\right)=3,25 \mathrm{~cm}<\delta_{\text {dop }}=12,5 \mathrm{~cm}$.

W Eurokodzie 1990 [4] (Załącznik A2) określono minimalne warunki ugięć mostów zapewniające określone poziomy komfortu podróżnych. Wytyczne te nie uwzględniają standardu utrzymania konstrukcji torowiska (podsypka, szyny, podkłady, złącza itp.). W opracowaniu [15] podano ostrzejsze ograniczenia ugięć w funkcji prędkości ruchu 
pociągów, zapewniające komfort podróżnych: $v<80 \mathrm{~km} / \mathrm{h} \delta_{\text {stat }} \leq L / 800,80 \leq v \leq 200 \mathrm{~km} / \mathrm{h}$ $\delta_{\text {stat }} \leq L /(15 v-400)$. Przy prędkości $v>200 \mathrm{~km} / \mathrm{h}$ należy wykonać dokładne obliczenia dynamiczne (analiza czasowa), ale $\delta_{\text {stat }} \leq L / 2600$. Rozpatrywana konstrukcja spełnia przytoczone wymagania, tj. $u_{\text {zmax }}=\delta_{\text {stat }}=3,25 \mathrm{~cm} \leq L /(15 v-400)=7500 \mathrm{~cm} /(15 \cdot 150-400)=$ $4,05 \mathrm{~cm}$, z zapasem rzędu $20 \%$.

\section{Podsumowanie}

Przeprowadzona teoretyczna analiza modalna kolejowej konstrukcji kratownicowej w nawiązaniu do wytycznych Eurokodów [4, 5] umożliwiła wyciągnięcie, na etapie prac projektowych, istotnych wniosków odnośnie przewidywanego zachowania się obiektu pod obciążeniem dynamicznym od taboru kolejowego. Konstrukcja jest niewrażliwa na drgania boczne (giętne poziome) wywołane np. wężykowaniem taboru $\left(f_{h \min }=1,24 \mathrm{~Hz}>f_{h 0}=\right.$ $1,20 \mathrm{~Hz})$ oraz na skrętne postacie drgań pomostu $\left(n_{T}=2,83 \mathrm{~Hz}>1,2 \cdot n_{0}=2,68 \mathrm{~Hz}\right)$. Pierwsza giętna częstotliwość drgań własnych zawiera się w przedziale normowym granicznych częstotliwości ( $n_{0}=2,23 \mathrm{~Hz} \in<1,83 \mathrm{~Hz}, 3,75 \mathrm{~Hz}>$ ), przy których nie jest wymagana zaawansowana analiza dynamiczna odpowiedzi konstrukcji (analiza czasowa, tj. całkowanie równań ruchu pod obciążeniem modelami pociągów szybkobieżnych HSLM). W świetle nomogramu na Rys. 6.9 normy PN-EN 1991-2 [5] nie jest wymagane określenie przyspieszeń w rezonansie oraz sprawdzenie ustroju na zmęczenie. Umożliwia to wydatne ograniczenie zakresu obliczeń obiektu na etapie prac projektowych. Ugięcia statyczne wywołane modelem obciążenia LM-71 $\times \Phi \times \alpha_{k}$ zapewniają spełnienie normowego warunku ugięć dopuszczalnych $\delta_{d o p}(v=150)$ dla bardzo dobrego komfortu podróżnych przy $b_{v}=1,0 \mathrm{~m} / \mathrm{s}^{2}$, zgodnie z poz. A2.4.4.3.2 PN-EN 1990 [4] oraz dodatkowe ograniczenia przedstawione $\mathrm{w}$ opracowaniu [15] $\left(u_{z \max }=3,25 \mathrm{~cm}<\delta_{\text {statmax }}(v)=4,05 \mathrm{~cm}\right)$.

Projektowana konstrukcja kratownicowa spełnia wymogi stawiane w normach PN-EN kolejowym obiektom mostowym w zakresie obciążeń dynamicznych i nie jest wymagana zaawansowana analiza czasowa $\mathrm{z}$ użyciem modeli pociągów szybkobieżnych HSLM oraz obliczenia zmęczeniowe. Zdaniem autorów, mimo "formalnego" spełnienia wymagań współczesnych przepisów warto przeprowadzić badania dynamiczne zrealizowanej konstrukcji pod próbnym obciążeniem. Umożliwią one ostateczne potwierdzenie założeń przyjętych na etapie projektu, ocenę skuteczności procedur Eurokodów, a ponadto mogą stanowić cenny materiał przy projektowaniu podobnych obiektów.

\section{Literatura}

1. Specyfikacja Istotnych Warunków Zamówienia „Prace na linii kolejowej E59 na odcinku Poznań Gtówny - Szczecin Dąbie”, PKP PLK S.A., Poznań 2014.

2. Id-2 (D-2) Warunki techniczne dla kolejowych obiektów inżynieryjnych. PKP-PLK S.A., Załącznik do zarządzenia nr 29/2005 Zarządu PKP-PLK S.A. z dnia 18 maja 2005.

3. Standardy techniczne - Szczegółowe warunki techniczne dla modernizacji lub budowy linii kolejowych do prędkości $v_{\max } \leq 200 \mathrm{~km} / \mathrm{h}$ i $250 \mathrm{~km} / \mathrm{h}$. Warszawa, 2010 .

4. PN-EN 1990 Eurokod 0. Podstawy projektowania konstrukcji.

5. PN-EN 1991-2 Eurokod 1. Oddziaływania na konstrukcje. Część 2: Obciążenia ruchome mostów.

6. Rozporządzenia MTiGM z dnia 10.09.1998 w sprawie warunków technicznych, jakim powinny odpowiadać budowle kolejowe i ich usytuowanie (Dz. U. nr 151 z 1998r., poz. 987) wraz ze zmianami z dnia 05.06.2014. 
7. UIC CODE 776-2. Design requirements for rail-bridges based on interaction phenomena between train, track and bridge. International Union of Railways, 2009.

8. Chmielowski T., Zembaty Z., Podstawy dynamiki budowli. Arkady, Warszawa, 1998.

9. He J., Fu Z.-F., Modal Analysis. BH, London, 2005.

10. Fryba L., Dynamics of railway bridges, T. Telford, 1996.

11. Goicolea J.M., Dominiquez J., Navarro J.A., Gabaldon F., New dynamic analysis methods for railway bridges in codes IAPF and Eurocode 1. Railway Bridges Design, Construction and Maintenance, Madryt, 2002.

12. Karaś S., Krasnowski A., Dostosowanie obiektów mostowych na CMK do dużych prędkości pociagów w świetle badań teoretycznych i doświadczalnych, Drogi i Mosty 12 (2013).

13. O'Brien E.J., Keogh L.D., Bridge deck analysis. E and FN Spon, London, 1999.

14. Oleszek R., Analiza dynamiczna mostów kolejowych w świetle współczesnych przepisów. Theoretical Foundations of Civil Engineering, OW PW, Warszawa, 2015.

15. Rakowski G., Kacprzyk Z., Metoda elementów skończonych w mechanice konstrukcji. OW PW, 2005.

16. Szafrański M., Żółtowski K., Modelowanie konstrukcji mostów pod kątem dynamicznym. Seminarium Mosty Kolejowe, Warszawa-Jachranka 2013.

17. Szcześniak W., Problemy ruchomych obciązeń w Polsce. Przegląd podstawowych pozycji literatury. Theoretical Foundations of Civil Engineering, OW PW, Warszawa, 1993.

18. Tshumi M., Railway bridges. basis of design of railway bridges, Seminar "Bridge Design with Eurocodes", JRC-Ispra, 2012.

19. Zobel H., Zbiciak A., Oleszek R., Michalczyk R., Mossakowski P., Numeryczna identyfikacja cech dynamicznych stalowo-betonowego mostu kolejowego, Drogi i Mosty 13 (2014).

20. Yang Y.B., Yau J.D., Wu Y.S., Vehicle-bridge interaction dynamics. WSP, Singapore 2004.

\title{
The evaluation of dynamic of designed truss railway bridge in the light of Eurocodes standards
}

\author{
Radosław Oleszek ${ }^{1}$, Mirosław Wyrzykowski ${ }^{2}$, Krzysztof Grej² ${ }^{2}$ Jerzy Bąk $^{2}$ \\ ${ }^{I}$ Department of Bridges, Faculty of Civil Engineering, Warsaw University of Technology, \\ e-mail: r.oleszek@il.pw.edu.pl \\ ${ }^{2}$ Pomost S.C., bridge design office, \\ e-mail:m.wyrzykowski@pomost.com.pl,k.grej@pomost.com.pl,j.bak@pomost.com.pl,
}

\begin{abstract}
According to the amendment of the "railway" Regulation of June 2014, railway bridges should be designed on the basis of PN-EN (Eurocode) standards, which extended the scope of computational analysis at the stage of structural design with dynamic issues. It includes theoretical modal analysis (eigenvalue problem) along with assessment of structural sensitivity to selected forms of vibration, traveler comfort and time-step analysis (integration of traffic equations under standard HSLM trains). In some cases, at planned train speeds $v \leq 200 \mathrm{~km} / \mathrm{h}$, the dynamic calculations of the system can be reduced to modal analysis. The study presents the evaluation of the design of the truss railway bridge with a span of $L_{t}=75.0 \mathrm{~m}$ in dynamic terms as required by Eurocodes. Moreover, the impact of applied construction solutions on the modal characteristics of the bridge is commented.
\end{abstract} FEM.

Keywords: truss bridge, railway bridge, dynamic analysis, modal analysis, Eurocodes, 